\title{
REVISTA PESQUISA EM FISIOTERAPIA
}

A Pesquisa na área da Fisioterapia, tanto por seu caráter disciplinar como por sua interdisciplinaridade natural com outras áreas do conhecimento, continua em franco desenvolvimento. Este fato é evidenciado pelo crescente número de artigos na área e pela qualidade observada pelo rigor metodológico com que vêm sendo realizadas as pesquisas produzidas em todo o território nacional. Estamos felizes por poder contribuir com uma parcela relevante desse crescimento que envolve a divulgação dos achados nos trabalhos científicos.

Esta edição, que corresponde ao número dois do terceiro volume, pode ser considerada como uma edição comemorativa porque foi com muita satisfação que recebemos a notícia de que fomos estratificados pelo WebQualis da Capes, em sua última edição, em cinco áreas de avaliação: Medicina I e II, Interdisciplinar, Ciências Biológicas e Biotecnologia (disponível em http://qualis.capes.gov.br/webqualis/principal.seam). Os estratos variaram de B4, B5 e C e acreditamos que estamos demonstrando com esse "bom começo" (já que só existimos há dois anos) que estamos no caminho certo da construção de um modelo adequado às tendências vigentes de divulgação do conhecimento na área de Fisioterapia e áreas afins.

Agora estamos trabalhando para crescer ainda mais e ampliar nosso alcance rumo à internacionalização do conhecimento produzido em Fisioterapia. Para isto, estamos ampliando mais uma publicação anual, o que significa que nossa periodicidade passará de semestral para quadrimestral e passaremos a aceitar artigos em língua inglesa a partir da próxima edição. Entramos em contato com fisioterapeutas dos Estados Unidos e da Europa para participarem de nosso corpo editorial e fomos muito bem recebidos. O modelo de acesso aberto e sem custos de publicação foi muito bem avaliado pelos pesquisadores que aceitaram nosso convite. Esperamos, com esta ação, estar contribuindo para ampliar a visibilidade de nossa produção nacional na área da Fisioterapia, ao mesmo tempo em que fortalecemos nossa profissão e incluímos nossos pares internacionais ampliando o diálogo aberto entre todos os fisioterapeutas do mundo.

Neste número, de acordo com nosso planejamento estratégico de desenvolvimento da qualidade de nossa revista com a meta de indexá-la no Scielo até 2015, passamos por um crivo elevado dos critérios de avaliação e apresentamos poucos artigos que foram selecionados por uma equipe qualificada e exigente de revisores cegos. Esses relatos selecionados envolvem as áreas de saúde do idoso, ergonomia, exercícios físicos em 
EDITORIAL

diferentes grupos e uma revisão sistemática em urologia de diferentes regiões brasileiras. Desejamos que todos aproveitem os achados destes estudos científicos e pedimos que deem suas contribuições para melhorarmos sempre nossa qualidade e nos tornarmos uma excelência para a divulgação da pesquisa em Fisioterapia.

Aproveito para desejar a todos os leitores um Feliz Natal e Próspero 2014!

Katia Nunes Sá

Fisioterapeuta, PhD

Editora Chefe da RPF

Escola Bahiana de M edicina e Saúde Pública 